\title{
A ilustração científica como parceira na conservação do Cerrado
}

\section{Scientific sketching as a partner in the conservation of the Cerrado Biome}

Texto de / Text by Prof. Marcos A. Santos-Silva, Dr.*

*Núcleo de Ilustração Científica - Instituto de Biologia, Universidade de Brasilia Contato do autor: marco.unb@gmail.com

Quando se fala de ilustração científica, a reação que temos é de, no mínimo, perplexidade. Alguns imaginam que se trata de uma área extinta ou em vias de extinção. Outros nem sabem do que se trata, principalmente fora do meio acadêmico. Mas, repassemos um pouco de história, para ver que nós, ilustradores científicos, somos herdeiros de uma tradição secular.

Nowadays, when somebody mentions scientific sketching, most people will be perplexed, at the least. Some will even think that it is an extinct - or all but extinct - undertaking. Others will not have a clue about what it is, especially if they do not belong to academic or scientific circles. However, a bit of history lets us see that scientific sketchers are the inheritors of a multi-secular tradition. 
Desenhar sempre foi para os humanos um ato espontâneo, mesmo antes do aparecimento de uma linguagem estruturada. Por volta de 15.000 anos atrás, no que se conhece como o "Período Magdalenense", humanos primitivos produziram desenhos magníficos que ainda hoje podem ser apreciados nas grutas do Sul da França ou Espanha, sendo Lascaux e Altamira duas de suas mais representativas expressões. Nunca saberemos ao certo porque tais imagens foram produzidas, mas a firmeza dos traços e o registro da anatomia dos animais denotam uma técnica precisa e um conhecimento profundo daqueles indivíduos sobre os seus modelos.

Talvez o primeiro registro que se tenha de uma obra contendo ilustrações científicas seja o herbário de Pedanios Dioscorides, obra conhecida como De Materia Medica, produzida por volta do ano $65 \mathrm{AD}$. Este tratado, embora não rigorosamente científico, foi reconhecidamente o mais famoso tratado de sua época sobre farmacologia. Continha descrições botânicas de ervas e produtos agrícolas, com enfoque em suas propriedades medicinais. Foi um verdadeiro sucesso editorial, sendo traduzido para o árabe, persa, latim e várias outas línguas.

Esta obra foi a base de vários herbários europeus posteriores. O original do De Materia Medica foi perdido há muito tempo, mas uma prestigiosa cópia pode ser encontrada em Viena: o chamado Codex de Juliana Anicia ou Codex Vindobonensis med. gr. 1. Esta obra comemorou em 2012 seu 1500 aniversário. O exemplar depositado na Biblioteca Nacional da Áustria é uma cópia de De Materia Medica, feita para a princesa imperial Juliana Anícia, por volta do ano 512, em Constantinopla. Ele é composto por 491 folios em velino, contendo mais de 400 ilustrações de plantas e animais. Pertenceu, entre outros, ao médico particular do sultão otomano Suleiman, o Magnífico. Foi comprado junto ao Império Otomano, provavelmente pelo embaixador flamengo; mais tarde foi adquirido por Maximiliano II de Habsburgo, chegando a Viena em 1569. Foi finalmente depositado na atual Biblioteca Nacional, em 1592, onde se encontra até hoje.
Sketching has always been a spontaneous pursuit for humans, even before the appearance of structured languages. Around 15,000 years ago, in the so-called "Magdalenean Period", primitive humans made magnificent sketches that can still be appreciated on the walls of several caves - such as those in Lascaux and Altamira, in France and Spain. We will never be sure about why these drawings were made, but the accurate lines and the clear-cut records of the animals' anatomy indicate that those artists had sharp technics and a deep knowledge of their models.

The first record of a work containing scientific sketches is probably the herbarium of Pedanios Dioscorides, known as De Materia Medica, written approximately in 65 AD. This work, although not strictly scientific, was nonetheless recognized as the most famous treatise on pharmacology. It contained botanical descriptions of herbs and agricultural products, with emphasis on their medicinal properties. It was an editorial success, having been translated into Arabic, Persian, Latin and several other languages.

Dioscorides' work was the base of many later European herbariums. The original of De Materia Medica was lost many centuries ago, but a confirmed copy can be found in Vienna. It is the so-called "Codex of Juliana Anicia", or the Codex Vindobonensis med. gr. 1. In 2012 this work completed its 1.500th birthday. The copy deposited at the National Library of Austria is a reproduction made from De Materia Medica, expressly for the imperial princess Juliana Anícia, approximately in 512, in Constantinople. It is composed of 491 folios in vellum, containing more than 400 illustrations of plants and animals. It belonged, among others, to the private physician of the Ottoman sultan Suleiman, the magnificent. The Flemish ambassador to the Ottoman Empire probably acquired it; it was later bought by Maximillian II, of Habsburg, having arrived in Vienna in 1569. Finally, in 1592, it was deposited in Austria's National Library, where it is until today. 
Durante a Idade Média, foram produzidos herbários ricamente ilustrados que serviam para instruir os praticantes das artes médicas sobre as plantas e as suas propriedades curativas ou letais. O correspondente para a zoologia eram os bestiários, que tinham uma finalidade educativa de informar sobre as qualidades dos animais e sobre os ensinamentos morais que podiam ser aprendidos a partir de seu conhecimento. A qualidade das ilustrações destas obras era muitas vezes questionável. Era prática comum a reprodução dos herbários e bestiários por monges copistas nos scriptoria dos mosteiros. Não havia preocupação com a acuidade da reprodução das plantas ou dos animais.

Com o Renascimento, começam a ser produzidos trabalhos com ilustrações mais naturalistas e surge uma preocupação maior com a correta reprodução dos detalhes das plantas. Os modelos passam a ser coletados na natureza para serem desenhados, e não mais simplesmente copiados de outras ilustrações que, por sua vez, eram cópias de cópias. Arte e ciência caminhavam juntas.

Com os "descobrimentos" de novas terras por Portugal e Espanha, uma quantidade enorme de novas espécies começou a chegar na Europa. Relatos de viagens eram muitas vezes ilustrados, porém as imagens desses relatos eram pouco mais que "retratos falados" das espécies - misturavam o real e o imaginário.

Nos séculos seguintes, as viagens às novas colônias eram frequentemente acompanhadas por naturalistas e artistas que faziam ilustrações de espécimes recém coletados, usando as cores naturais, mais fiéis que as imagens feitas a partir de espécimes preservados em álcool ou como exsicata.

Muitas publicações cientificas tiveram as suas origens nesta época. Uma das mais antigas, publicada initerruptamente até hoje, é a Curtis Botanical Magazine, que desde 1787 publica pequenas monografias botânicas, sempre acompanhadas de ilustrações coloridas das plantas focalizadas e de desenhos em preto e branco de suas dissecações.
During the Middle Ages several richly illustrated herbariums were produced. They were used to teach medical practitioners about plants and their curative - or lethal - properties. In the field of zoology, bestiaries corresponded to herbariums. They had the educational mission of informing about the qualities of animals and about the moral lessons that could be learned by those who read them. The quality of the illustrations in these volumes was questionable. The common practice was the reproduction of herbariums and bestiaries, drawn by monks who worked in the scriptoria of the monasteries. There was little concern about the accuracy of the reproduction of plants and animals.

In the age of the Renaissance, in which many herbariums and bestiaries were produced, there was an increased concern with the correct reproduction of the details of plants and animals. Models started to be collected in nature. Copying older illustrations, which in their turn were copies of copies, was discontinued. Art and science improved at the same pace.

As Portugal and Spain "discovered" new lands, an enormous amount of new species started to arrive in Europe. Travel narratives to these lands were frequently illustrated, but the images contained in them were little more than "witness descriptions" of the species they mixed reality with the imaginary.

In the following centuries, expeditions to the colonies frequently included naturalists and artists. They made their illustrations based on recently collected specimens, recording their natural colors, achieving a higher degree of authenticity than images that used models that had been preserved in alcohol or as exsiccates.

Many scientific publications have their origins connected to the era of these expeditions. One of the oldest is Curtis Botanical Magazine, published continuously from 1787 until today. It contains short botanical monographs, always accompanied by colored illustrations of the featured plants and by drawings in black and white of their dissected parts. 
No Brasil, um grande marco na ilustração científica foi a migração da família real portuguesa para terras brasileiras, em 1808. A "abertura dos portos" que se seguiu permitiu a naturalistas, europeus principalmente, a descoberta do que até então era conhecido apenas pelos portugueses.

Outro grande impulso para o conhecimento de nossas espécies foi o casamento do príncipe herdeiro $D$. Pedro com a arquiduquesa Leopoldina de Habsburgo. Em sua comitiva, D. Leopoldina trouxe inúmeros cientistas naturalistas, tais como von Martius, Spix e Natterer. A natureza brasileira começou a ficar conhecida pelo mundo acadêmico. Artistas naturalistas e ilustradores acompanhavam quase todas as expedições realizadas pelo interior do Brasil. Foi o início de uma atividade que até hoje ocupa lugar importante na comunicação científica.

Qual seria, no entanto, a função da ilustração científica nos dias de hoje, em uma época de fotografias digitais, em um mundo cada vez mais conectado pela Internet? A resposta é simples: é a mesma de sempre. Ela auxilia o pesquisador na comunicação dos resultados de suas descobertas. A ilustração científica facilita a comunicação não apenas entre pares, mas também entre o meio acadêmico e o público em geral.

O velho ditado que diz que uma imagem vale mais do que mil palavras poderia ter sido cunhado para definir a ilustração científica. A imagem ilustrada revela aquilo que se quer explicar. Podem ser realçados detalhes anatômicos importantes, as cores, ou a relação entre as partes. Uma fotografia, por melhor e mais sofisticada que possa ser o aparelho que a produz, ainda tem limitações que podem ser contornadas pelas ilustrações. Uma foto macro revela detalhes incríveis, mas limitações de profundidade de campo obscurecem detaIhes importantes; aparelhos fotográficos em multicamadas ainda são acessíveis a poucos pesquisadores, por causa do seu preço elevado e, pior ainda, elas não são portáteis a ponto de serem levados facilmente para o campo. De toda forma, a fotografia é, sim, uma grande aliada da ilustração científica. Cada uma
An important date for the development of scientific illustration in Brazil was 1808: that was the year that the Portuguese royal family migrated to its Brazilian colony. This led to the "opening" of the colony's ports to international trade and travel. This allowed naturalists, particularly non-Portuguese Europeans, to travel around the Brazilian territory and discover things that until then were known only by Portuguese colonizers.

In 1817 the recording of Brazilian species received a new incentive: the archduchess Leopoldina of Habsburg, from Austria, arrived in Brazil to marry with Portuguese prince Don Pedro. She brought with her several scientists interested in Brazilian nature - Martius, Spix and Natterer became the most famous of them. Brazilian nature became progressively well known by the academic world. Artists, naturalists and illustrators joined almost all expeditions to the vast Brazilian interior. This was the beginning of an activity that still holds an important place in scientific communication.

One might ask: what is the current role of scientific illustration, in the era of digital photography, in a world increasingly interconnected by the Internet? The answer is simple: its role is the same as it always was. It helps researchers report the results of their findings. Scientific illustration makes communication easier, not only among peers, but also to the academic world and the general public.

The old saying that one image is worth a thousand words could have been coined to define scientific sketching. The sketched image reveals that which we want to explain. Important anatomical details, colors, relation between parts - all can be enhanced. A photo, even taken with a highly sophisticated camera, still has limitations that may be counteracted by sketches. A macro photo reveals incredible detail, but limitations in field depth hide important aspects; besides, multi-layer cameras are accessible only to a few researchers, because they are so expensive; worse than that, they are not portable and cannot be taken easily to the field with. Nonetheless, photography is indeed a strong ally of scienti- 
revela aspectos importantes dos modelos em foco.

O Brasil desenvolveu uma grande tradição na ilustração científica, principalmente na ilustração botânica. Os irmãos Demonte, Maria Werneck de Castro - que nos anos 1960 trabalhou brevemente para o Departamento de Botânica da UnB - e, claro, Margaret Mee, são apenas alguns dos nomes de maior destaque. A extinta Fundação Botânica Margaret Mee foi responsável pela formação de um grande número de ilustradores botânicos que vêm levando adiante esta arte/ciência. Muitos de seus ex -bolsistas formam novas gerações de ilustradores. A maioria encontra-se nas regiões Sul e Sudeste, mas alguns desses ex-bolsistas vivem e trabalham no Centro Oeste.

A Universidade de Brasília tem importante pioneirismo na área: em 1999 criou um Núcleo de Ilustração Científica, dentro do seu Instituto de Ciências Biológicas. Outras universidades seguiram o seu exemplo. O núcleo oferece diversas disciplinas na área de ilustração, não apenas para alunos do curso de biologia, mas para todos alunos interessados. Atualmente, oferece sete disciplinas para a graduação e uma para o programa de pós-graduação em ecologia. As disciplinas abrangem desde técnicas básicas do grafite e nanquim até as mais sofisticadas, como a aquarela ou o acrílico ("Ilustração Científica" - 125644, e "Técnicas Avançadas em Ilustração Científica" - 126241). Outra disciplina ("Materiais em Ilustração Científica" - 100919) explora técnicas alternativas, como um resgate do passado, como, por exemplo, as técnicas da têmpera a ovo e da ponta de prata. Disciplinas de "Estágio" e de "Práticas de Campo" também são oferecidas pelo núcleo.

A atuação dos ilustradores científicos geralmente se associa a institutos de pesquisa (INPA, FIOCRUZ, EMBRAPA, jardins botânicos) ou universidades. A maioria destes ilustradores trabalha, entretanto, como free lancers, já que são raras as instituições que têm em seus quadros vaga específica para ilustradores científicos. Não podemos esquecer daqueles que trabalham para as grandes indústrias farmacêuticas na produção de imagens utilizadas fic sketching. Each reveals important aspects of the models.

Brazil has developed a strong tradition in scientific sketching, particularly concerning plants. The Demonte brothers, Maria Werneck de Castro (who worked briefly in the 1960s at the Universidade de Brasilia's Department of Botanics) and, of course, Margaret Mee are just a few of the more prominent names. The now extinct Margaret Mee Botanical Foundation trained a large number of botanical sketchers who remain quite active. Some of its alumni are training new generations of sketchers. Most of them are located in Brazil's South and Southeast, but some of them live and work in Brazil's Midwest region.

The Universidade de Brasilia was a pioneer in the field of sketching: in 1999 it created a Scientific Illustration Nucleus, as part of its Institute of Biological Sciences. Other universities have followed its example. The unit offers several courses in sketching to students of biology and other fields. It currently offers seven courses to undergraduate students and one course to graduate students in the field of ecology. The classes teach basic techniques in graphite and nanquim and advanced techniques, such as watercolors and acrylic. The course called "Materials for Scientific Sketching" explores alternative techniques, some of them used in the past. Students also engage in internships and field trips. Brazilian scientific sketchers usually work in research institutions (INPA, FIOCRUZ, EMBRAPA, botanical gardens) and universities. Most of them work as free lancers, because very few institutions offer permanent positions for scientific illustrators. Some also work for large pharmaceutical companies, drawing images to be used on labels and on publicity materials of new medicinal products.

Another positive fact is the existence of an active Association of Scientific Sketchers of the Brazilian Midwest (AICCOB is the Portuguese language acronym), founded in 2009. Its members live and work in Brasilia, Anápolis, Goiânia and Campo Grande. 
nas embalagens dos produtos e no material de divulgação de novos medicamentos, com imagens que mostram a interação da droga com receptores celulares etc.

É necessário destacar também a existência de uma Associação dos Ilustradores Científicos do Centro Oeste Brasileiro (AICCOB), fundada em 2009. Esta associação tem por objetivos fortalecer e divulgar a ilustração científica na região Centro Oeste. Ela tem membros em Brasília, Anápolis, Goiânia e Campo Grande.

$\mathrm{Na}$ atualidade, a ilustração tem um papel muito maior que aquele que lhe é tradicionalmente atribuído. Além da comunicação científica, a ilustração está tendo um papel cada vez maior na conscientização ambiental. É conhecida a noção de que só se preserva aquilo que se conhece, e este é justamente um dos papéis de maior atualidade da ilustração científica: dar a conhecer ao público leigo a beleza e riqueza da biodiversidade brasileira. Ao chamar a atenção para uma espécie ameaçada ou ao revelar em grandes formatos a complexidade de espécies pouco visíveis a olho nu, mas não menos importantes para o equilíbrio da natureza, a ilustração presta o serviço de revelar a beleza e chamar a atenção para a sua conservação.

Um outro campo de atuação para a ilustração científica, relacionado à conscientização e à conservação das espécies, é a produção de guias de campo. É triste vermos como um país com a riqueza natural do Brasil ainda é engatinha na produção desses guias. De poucos anos para cá ocorreu, felizmente, um forte crescimento desta produção. Muitos guias, entretanto, são fotográficos, apresentando problemas inerentes às fotografias. A formação de uma massa crítica de bons ilustradores científicos pode corrigir essa distorção. Quanto mais material deste tipo for produzido, para todas as faixas etárias, mais as nossas crianças crescerão sensibilizadas para a natureza à sua volta e mais o público em geral reconhecerá a importância das questões ambientais.

A consciência ambiental dos ilustradores em geral e a sua paixão pelo que fazem e pelos modelos que ilustram são as suas bandeiras
Currently scientific sketching plays a role that is much larger than what is usually attributed to it. Along with scientific communication, sketching is carving out an expanding role in environmental awareness. It is commonly said that people will preserve only what they know and this has been one of the most up to date role of scientific sketching: to make the general population aware of the beauty and richness of Brazilian biodiversity. Sketching, when it focuses on an endangered species or when uses large strokes to reveal the complexities of species that are invisible to the naked eye, allows beauty to become well known and emphasizes the importance of its conservation.

Scientific sketching has been active in another field linked to environmental awareness and to the conservation of species - the production of field guides. It is disheartening that Brazil, a country so rich in natural beauties and wonders, is so behind in the production of these guides. Fortunately, over the last few years, there has been strong increase in the number of guides made available to the public. Many of them, however, are illustrated by photographs and suffer from the limitations inherent to this medium. The training of a critical mass of good scientific sketchers will allow the correction of this distortion. The more guides we produce, for all age groups, the more our children will be sensitive to the aspects of nature around them and the general public will recognize the importance of environmental issues.

The environmental awareness of scientific sketchers and their passion about their work and about the models that they draw are their banners in favor of nature preservation. Sketchers living in Brazil's Midwest region are particularly sensitive to the problems generated by the alarming rate of reduction of the native expanses of Cerrado, the savanna formation typical of the region. When they depict components of the Midwest's fauna and flora, the sketchers make their contribution, even if modestly, to the struggle in favor of the Cerrado.

Although Brazilian scientific illustration is less expressive than that of other countries, it has generated several works worthy of being 
na luta a favor da preservação da natureza. Em especial, os grupos do Centro Oeste são muito sensíveis aos grandes problemas relacionados à redução alarmante das áreas do Cerrado original. Ao ilustrar espécies da fauna e flora regionais, os ilustradores procuram dar a sua contribuição, por modesta que seja, para essa luta.

Apesar de haver uma produção menos expressiva do que em outros países, principalmente tendo em vista a nossa rica biodiversidade, existe uma grande quantidade de obras dignas de menção que contêm ilustrações científicas sobre a nossa fauna e flora. A Flora Brasiliensis, produzida entre 1840 e 1906 por von Martius, Eichler e Urban, ainda é referência internacional. Ela tem 15 volumes, com 10.367 páginas, ricamente ilustradas. A obra pode ser acessada na íntegra pelo seguinte endereço eletrônico: $h$ ttp://florabrasiliensis. cria.org.br/index Publicações esporádicas trazem muitas ilustrações de alta qualidade, tais como os vários livros de Margaret Mee sobre a flora brasileira, ou Árvores históricas na paisagem de Curitiba, produzido pelo Centro de Ilustração Botânica do Paraná.1 Algumas obras de cunho científico também podem ser mencionadas, como Botânica - Introdução à Taxonomia Vegetal, do professor Joly, 2 ou Plantas do Brasil. Espécies do Cerrado, do professor Ferri.3 Ambas con6têm ilustrações precisas e elegantes que permitem a identificação das espécies retratadas. No campo da zoologia, infelizmente nunca tivemos obras da mesma envergadura, mas foram produzidos vários guias de campo, principalmente na área da ornitologia, com ilustrações de grande qualidade. Um exemplo é Birds of Brazil, de Ber van Perlo.4 Outro exemplo é o belo livro de Emílio Goeldi, Álbum de Aves Amazônicas,5, um clássico.

A seguir, apresentamos uma pequena galeria de imagens, gentilmente cedidas por alguns membros da Associação dos llustradores Científicos do Centro Oeste Brasileiro. mentioned. The Flora Brasiliensis, organized between 1840 and 1906 by von Martius, Eichler and Urban, remains as an international reference. It has 15 volumes, with a total of 10,367 richly illustrated pages. It can be accessed in full at <http://florabrasiliensis.cria. org.br/index>

Sporadic publications sometimes include quality illustrations, such as the several books by Margaret Mee about the Brazilian flora, or the book entitled "Historic trees in the landscape of Curitiba". 1 We can mention also scientific books, such as "Botanics - Introduction to Vegetal Taxonomy", by Joly,2 or "Plants of Brazil - Species of the Cerrado", by Ferri.3

In the field of zoology, unfortunately, we do not have such prominent oeuvres. However, there are several very well illustrated field guides, particularly in the field of ornithology. One of them is Birds of Brazil, by Ber van Perlo.4 Another is the beautiful book by Emilio Goeldi, "Album of Amazonian Birds", a classic. 5

Following this text, we present a small gallery of plant and animal sketches, kindly released for publication by several members of AICCOB.

\section{Works cited}

1. Centro de Ilustração Botânica do Paraná. Árvores Históricas na Paisagem de Curitiba. Gramofone Produtora Cultural, 2005.

2. Joly, A. B. Botânica. Introdução à taxonomia vegetal. Companhia Editora Nacional, 1976.

3. Ferri, M. G. Plantas do Brasil. Espécies do Cerrado. Editora Edgard Blucher Ltda, 1969.

4. Perlo, B. van Birds of Brazil. Oxford University Press, 2009.

5. Goeldi, E. Álbum de Aves Amazônicas. Editora Universidade de Brasília, 1981. 


\section{Obras citadas}

1. Centro de llustração Botânica do Paraná. Árvores Históricas na Paisagem de Curitiba. Gramofone Produtora Cultural, 2005.

2. Joly, A. B. Botânica. Introdução à taxonomia vegetal. Companhia Editora Nacional, 1976.

3. Ferri, M. G. Plantas do Brasil. Espécies do Cerrado. Editora Edgard Blucher Ltda, 1969.

4. Perlo, B. van Birds of Brazil. Oxford University Press, 2009.

5. Goeldi, E. Álbum de Aves Amazônicas. Editora Universidade de Brasília, 1981. 


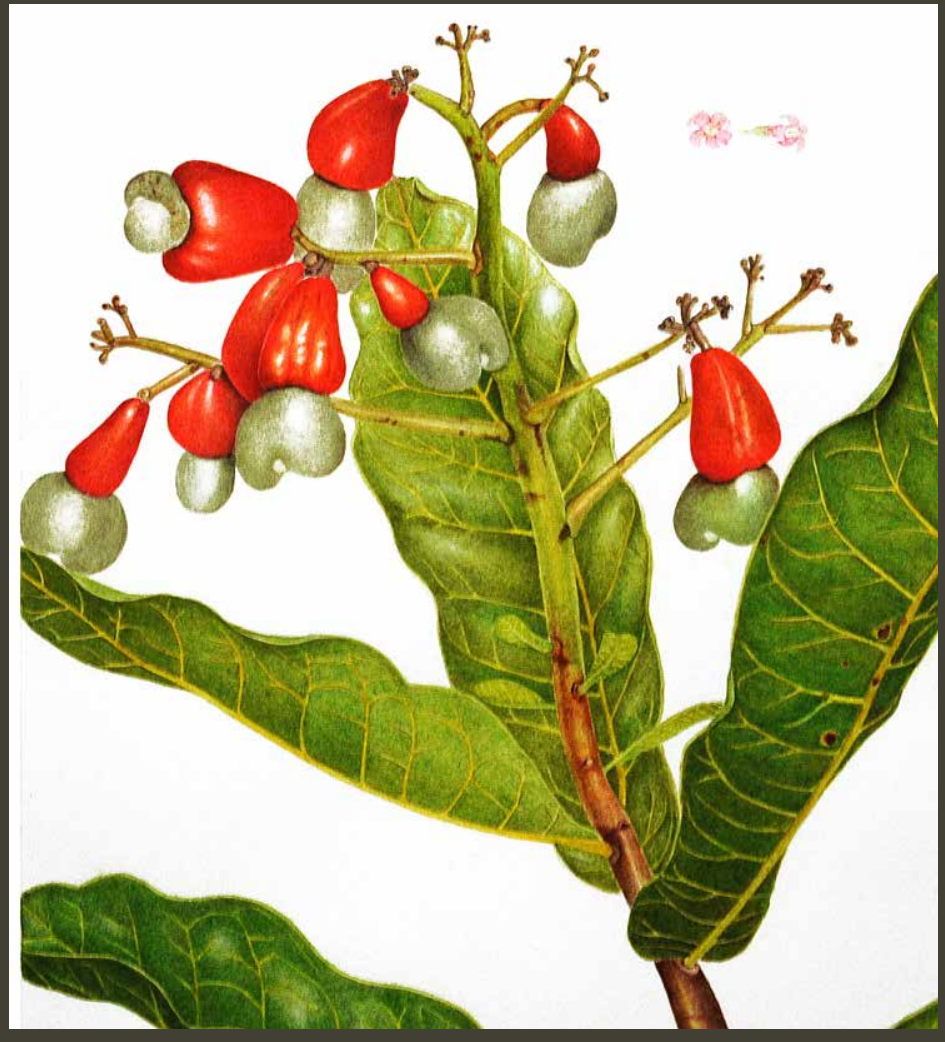

Anacardium humile A.St.-Hil. 1831

O cajuzinho-do-cerrado é uma arbustiva, nativa do Brasil, com ocorrência comum em todo o Bioma Cerrado. Pode atingir $80 \mathrm{~cm}$. O fruto verdadeiro (castanha) e o pseudo fruto (cajuzinho) podem ser consumidos e são muito utilizados na confecção de doces e compotas

Wilson Miguel - 2009

\section{Anacardium humile A.St.-Hil. 1831}

The "cajuzinho-do-cerrado" is a native Brazilian shrub, found along the entire Cerrado Biome. Its height may reach 80 centimeters. Its real fruit (similar to the cashew nut) and its pseudo-fruit (pulp) can be consumed by humans and are commonly used in sweets and compotes.

Author: Wilson Miguel - 2009

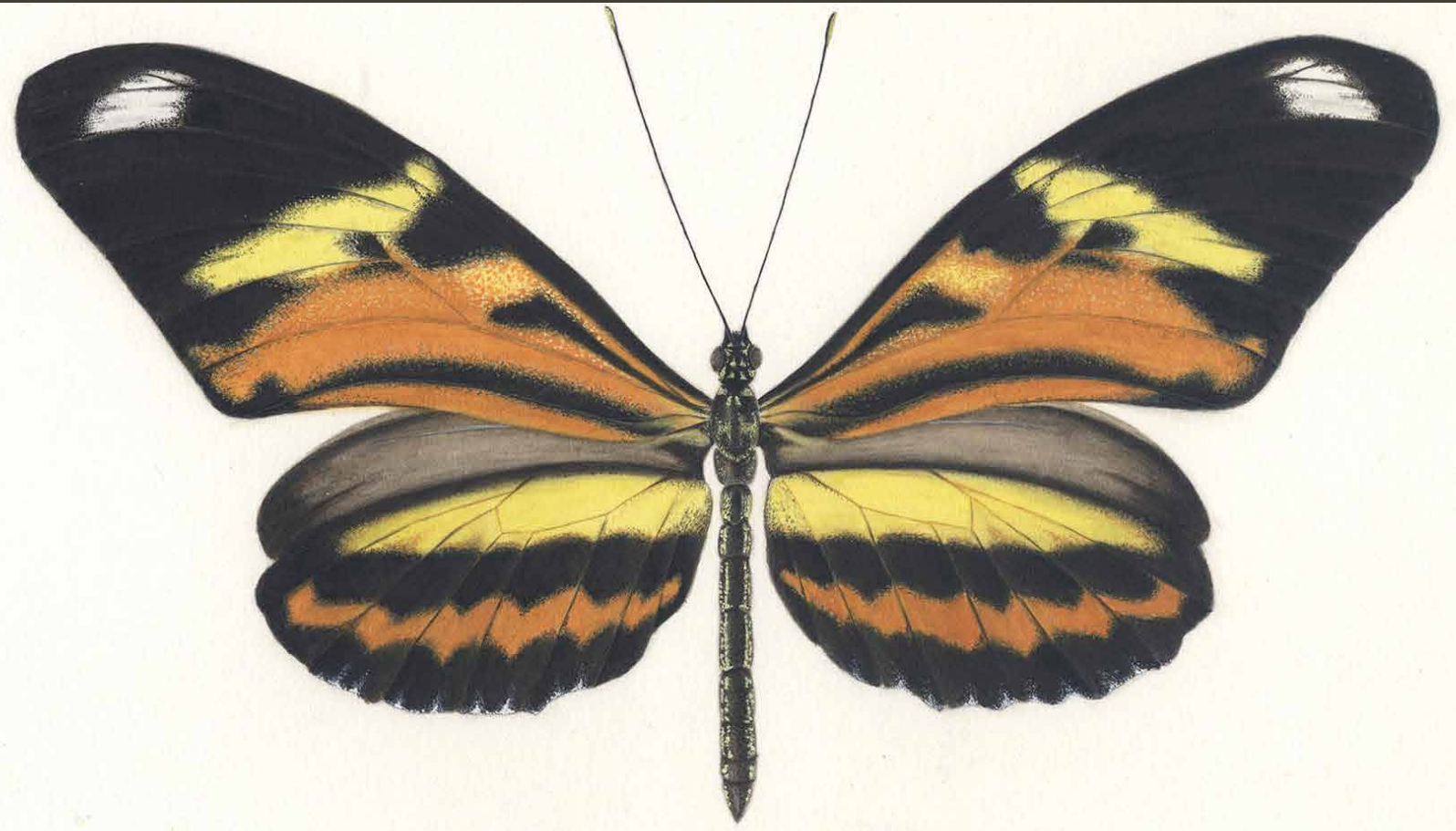

\section{Heliconius ethilla Godart 1819}

Esta borboleta da família Nymphalidae é encontrada do Pananá ao sul do Brasil. Seu hábitat são as margens de florestas. Tem cerca de 60 a $70 \mathrm{~mm}$ de envergadura de asa. Suas larvas alimentam-se de espécies de Passiflora. Os adultos apresentam vôo lento, normalmente perto do solo, e alimentam-se em plantas herbáceas, especialmente as com flores avermelhadas como o Cambará.
Heliconius ethilla Godart 1819

This butterfly of the family Nymphalidae is found in Southern Brazil, in the state of Paraná. Its habitat lies on forest edges. Its wingspan measures between 60 to 70 millimeters. Its larvae eat Passiflora species. Adults fly slowly, usually close to the ground and feed on herbaceous plants, particularly those that have red flowers, like the cambará.

Author: Bruno Benoliel - 2009 

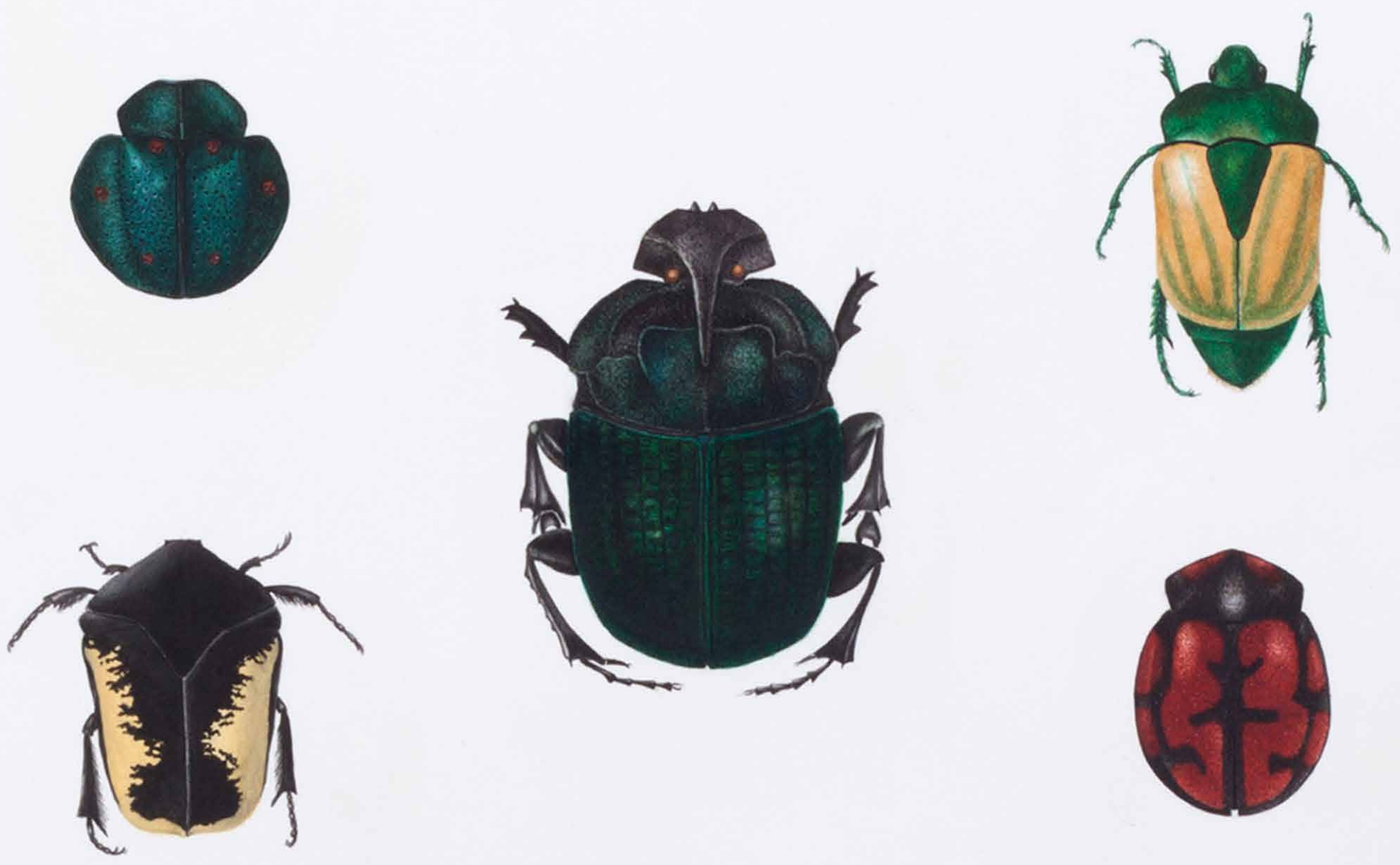

\section{Coleópteros do Cerrado}

Os coleópteros compõem a maior Ordem da classe Insecta, Seu número de espécies é maior que de todos os animais e vegetais juntos. Ocupam praticamente todos os Biomas do planeta, não sendo encontrados apenas dentro dos oceanos. Possuem uma infinidade de funções nos ecossistemas, sendo importantes recicladores de matéria orgânica.

Marcos Santos-Silva - 2008

\section{Coleoptera of the Cerrado}

Coleoptera form the most numerous Order of the class Insecta. The number of species belonging to the Order is larger than the number of all animals and plants counted together. They are present in practically all biomes of the planet; only in oceans have they not been found. They have numerous functions in ecosystems, including that of important recyclers of organic matter.

Author: Marcos Santos-Silva - 2008 
Ananas ananassoides (Baker) L.B. Sm. 1939

Também conhecido como ananás de raposa, esta Bromeliaceae pode atingir até 1 metro de altura, sendo nativa do Brasil, Argentina e Paraguai. Possui inflorescências subcilíndricas com flores roxas. É muito utilizado para fins decorativos e paisagísticos.

José Carlos Menezes - 2010

Ananas ananassoides (Baker) L.B. Sm. 1939

Also known as "ananás de raposa", this Bromeliaceae, is native of Brazil, Argentina and Paraguay. It can reach up to 1 meter in height. It has subcylindrical inflorescences, with purple flowers. It is widely used as an ornamental and in landscaping.

Author: José Carlos Menezes - 2010

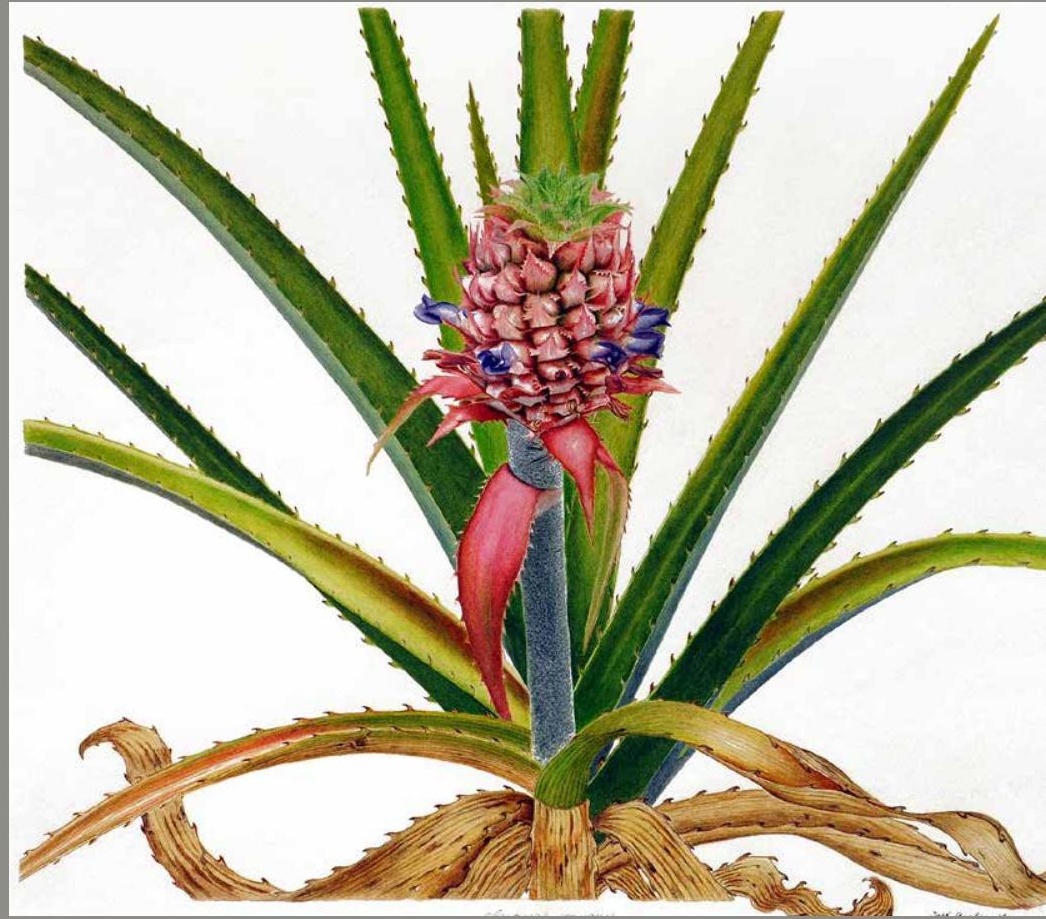

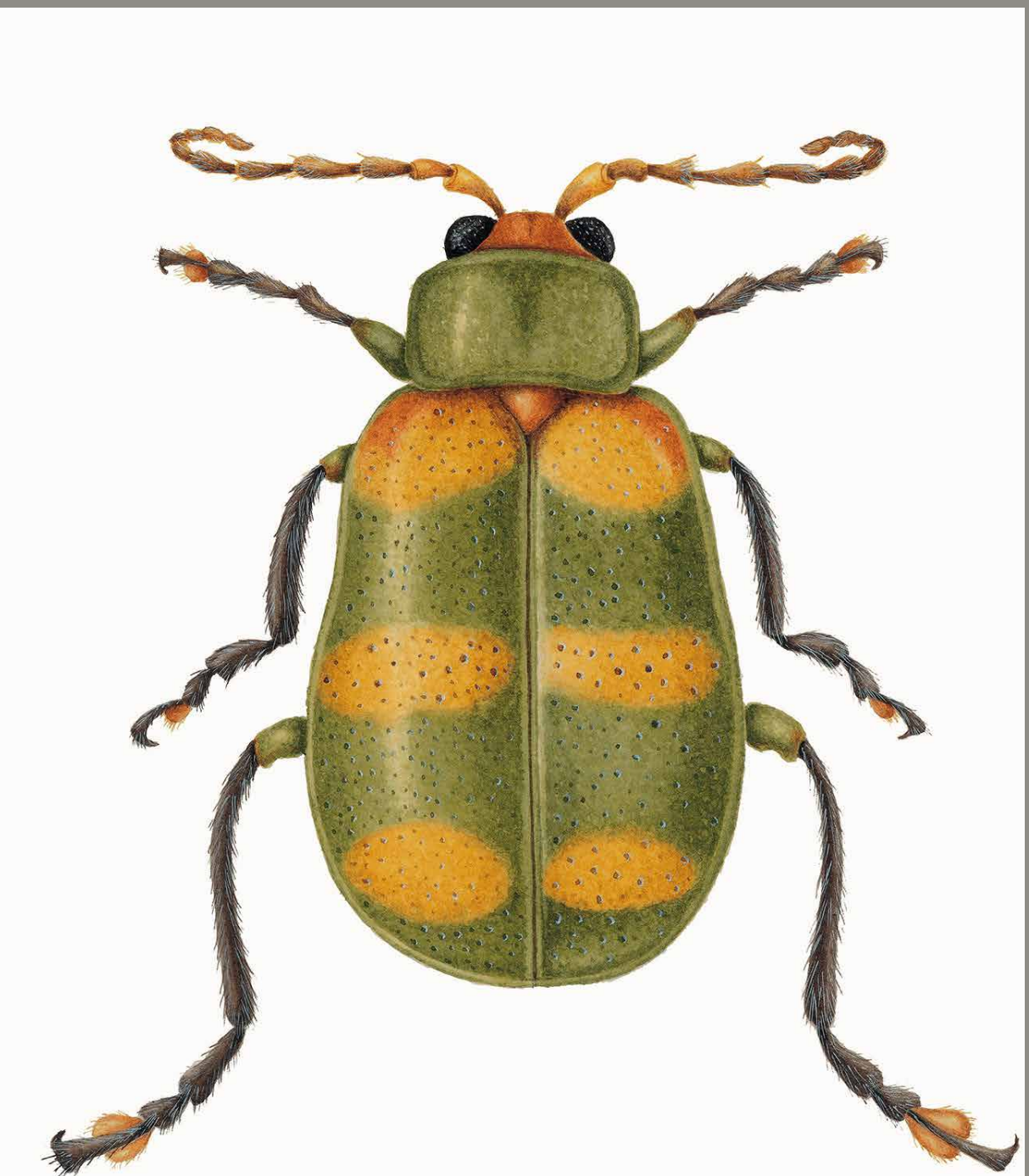

\section{Diabrotica speciosa Germar 1824}

Este besouro da família Chrysomelidae. 0 adulto pode chegar a no máximo $6 \mathrm{~mm}$ de comprimento, mas apesar de seu tamanho, suas larvas podem causar grandes danos às culturas do milho, impedindo o desenvolvimento normal da planta que apresenta um sintoma característico conhecido como pescoço de ganso, resultado do ataque à raiz do milho em desenvolvimento.

Marcos Santos-Silva - 2009

\section{Diabrotica speciosa Germar 1824}

This beetle is from the family Chrysomelidae. An adult measures up to 6 millimeters in length. Despite its small size, its larvae can cause serious damages to corn plantations, hindering normal plant growth. When the corn's roots are attacked by this beetle, the plant takes on an awkward shape called "goose neck".

Author: Marcos Santos-Silva - 2009 
O Lobo Guará é um canídeo da America do Sul, é considerado pelo Instituto Chico Mendes uma espécie ameaçada de extinção. Pode atingir 95 a $115 \mathrm{~cm}$ de comprimento e até $30 \mathrm{~kg}$. Características marcantes são as grandes orelhas e as pernas longas e finas. Seu habitat são as pradarias e matagais, com campos abertos de vegetação arbustiva.

Marcos Santos-Silva - 2008

\section{Chrysocyon brachyurus Illiger 1815}

The maned wolf is native of South America. It belongs to the Canidae family. Brazil officially considers it to be a species endangered with extinction. It can reach between 95 and 115 centimeters in length and weighs around 30 kilograms. Its most telling traits are its long ears and its long and thin legs. Its habitats are open prairies and wooded areas covered by shrubs.

Author: Marcos Santos-Silva - 2008

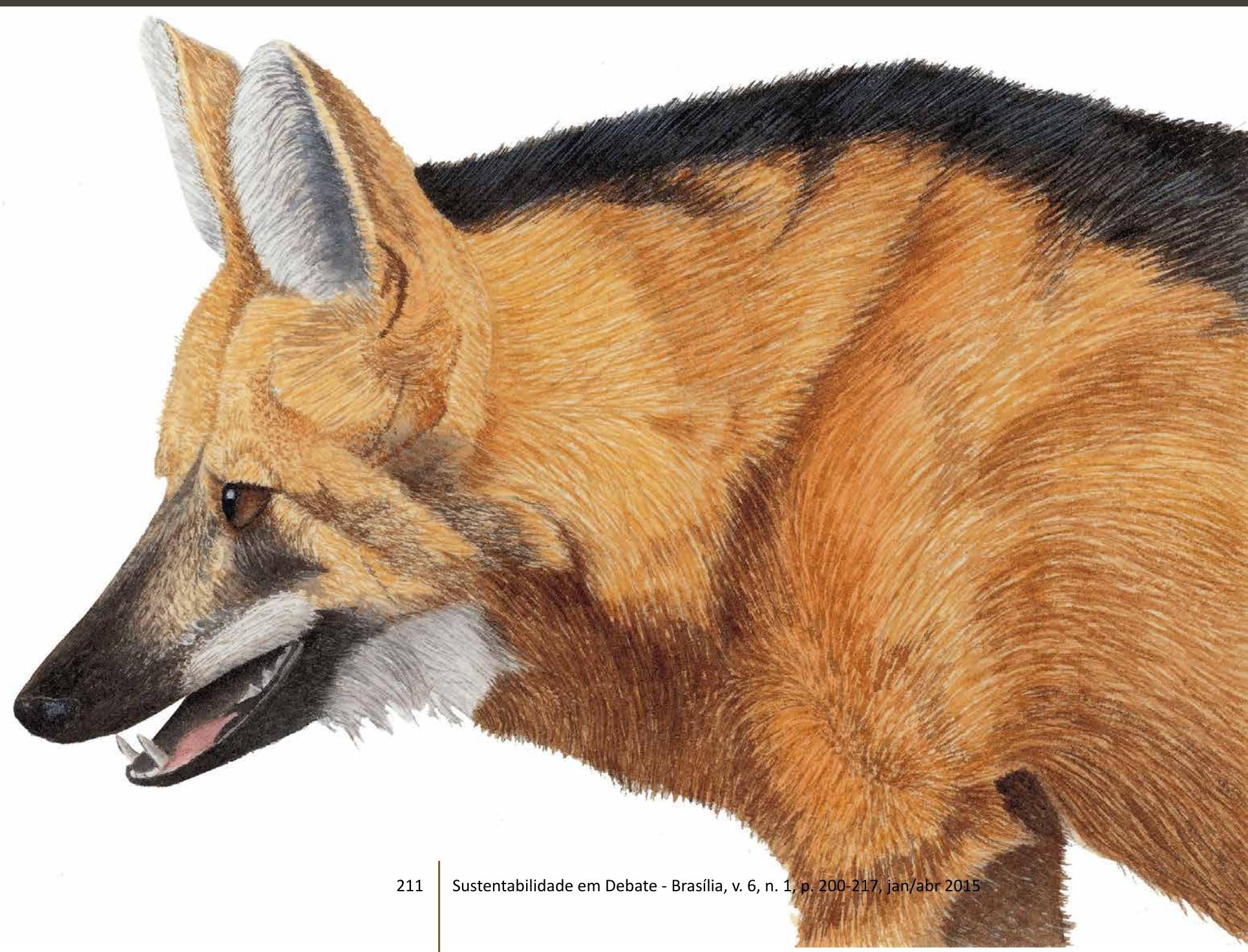




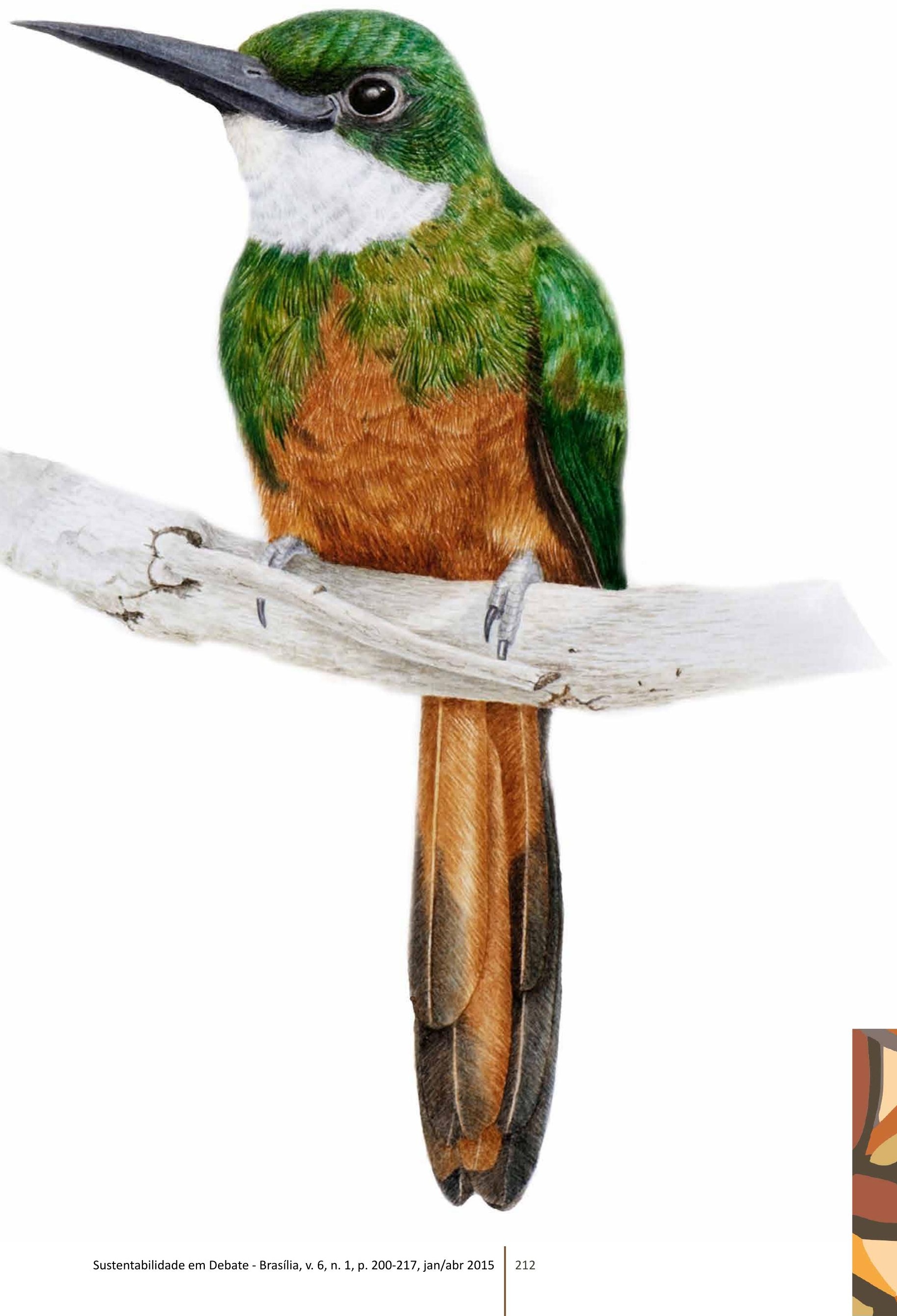




\section{Galbula ruficauda Cuvier 1816}

Conhecida popularmente como Ariramba de cauda ruiva, pode ser muitas vezes confundida com beija flores, devido a seu bico fino e longo e penas verde iridescentes Entretanto não apresenta nenhum parentesco com aqueles. Pode chegar a $24,5 \mathrm{~cm}$. É interessante observar seu comportamento de caça, já que graças a sua destreza e velocidade é capaz de apanhar insetos, tão pequenos quanto uma abelha, quando estes passam voando perto de seu poleiro,. Após apanhar a presa, volta para o ponto de partida e bate-a repetidamente contra o poleiro, a fim de retirar as asas e quebrar eventuais carapaças.

Marcos Santos-Silva - 2008

\section{Galbula ruficauda Cuvier 1816}

Its popular name is "ariramba de cauda ruiva". It is commonly confused with hummingbirds, due to its long beak and its iridescent green feathers. However, it is not related to hummingbirds. Its wingspan may measure up to 24.5 centimeters. Its hunting behavior is quite interesting. Using its precise and swift flight, it manages to grab even small insects (like bees) in the air, as they pass near its perch. After capturing its prey, this bird returns immediately to its perch and slams the prey repeatedly against the perch. It does this to get rid of wings and break carapaces.

Author: Marcos Santos-Silva - 2008 
Conhecida popularmente como bolsa de pastor devido a forma de seus frutos, ela pertence a família Bignoniaceae, sendo nativa do Brasil e importante componente da vegetação do Cerrado. As flores amarelas, tubulares e inodoras produzem e armazenam grande quantidade de néctar, o que atrai beija flores, seus polinizadores. Suas raízes são também utilizadas na medicina popular contra doenças de pele.

\section{Newma Gusmão - 2011}

\section{Zeyheria montana Martius 1826}

Popularly known as "bolsa de pastor", it belongs to the Bignoniaceae family. It is native to Brazil and is an important member of the Cerrado vegetation. Its yellow, tubular and scentless flowers produce and store a large amount of nectar, thereby attracting hummingbirds, their pollinators. Its roots are used in popular medicine against skin ailments.

Author: Newma Gusmão - 2011

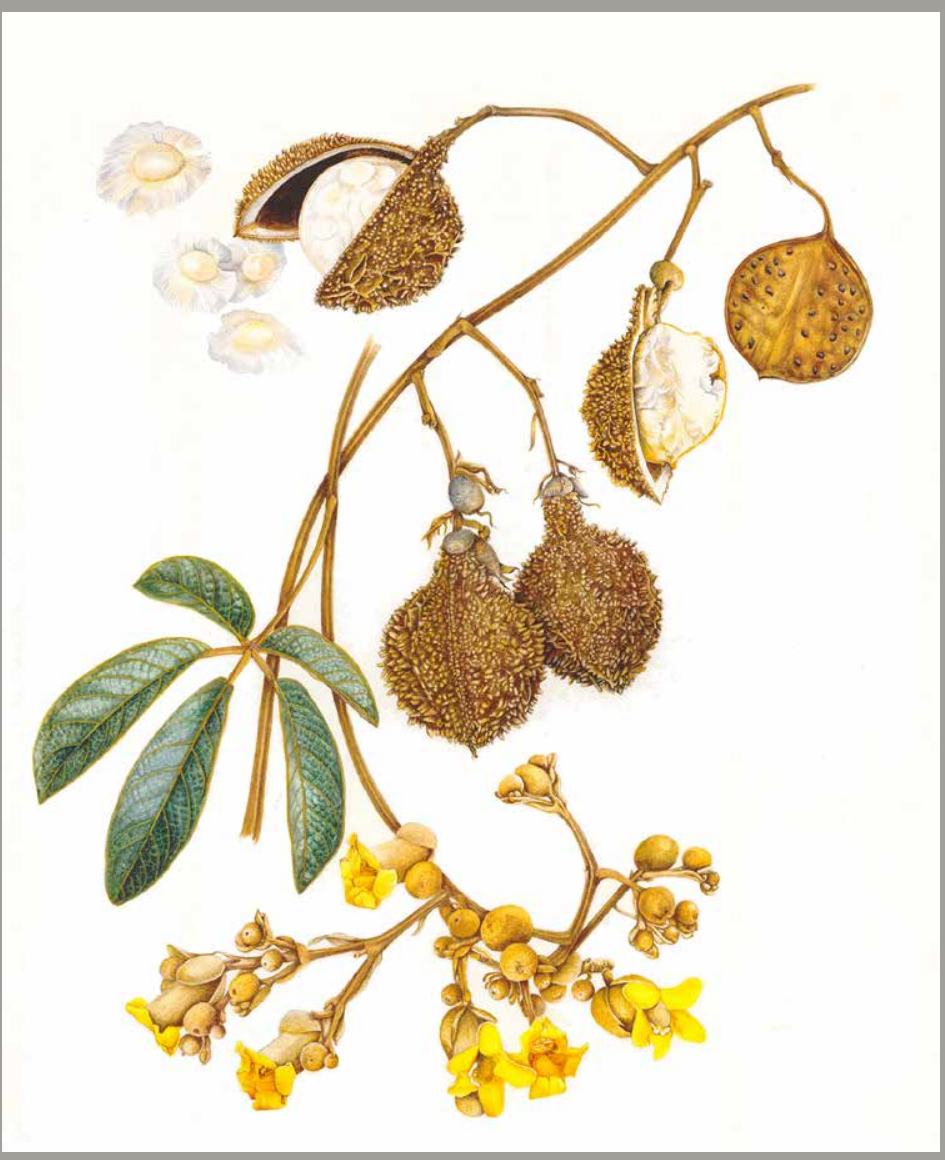

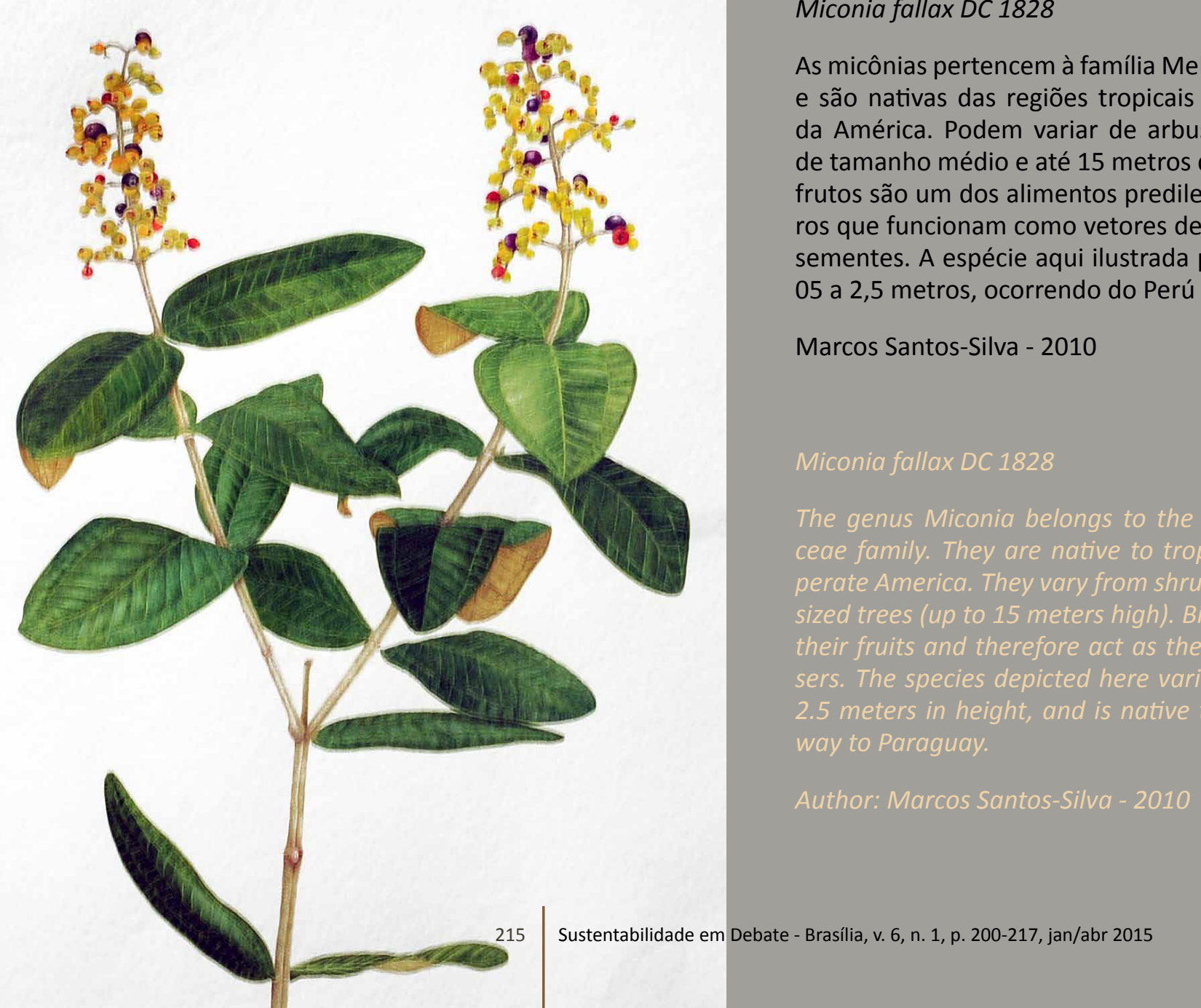

As micônias pertencem à família Melastomataceae e são nativas das regiões tropicais e temperadas da América. Podem variar de arbustos a árvores de tamanho médio e até 15 metros de altura. Seus frutos são um dos alimentos prediletos dos pássaros que funcionam como vetores de dispersão das sementes. A espécie aqui ilustrada pode variar de

\section{The genus Miconia belongs to the Melastomata- ceae family. They are native to tropical and tem- perate America. They vary from shrubs to medium- sized trees (up to 15 meters high). Birds love to eat their fruits and therefore act as their seed disper- sers. The species depicted here varies from 0.5 to 2.5 meters in height, and is native to Peru all the} Author: Marcos Santos-Silva - 2010 


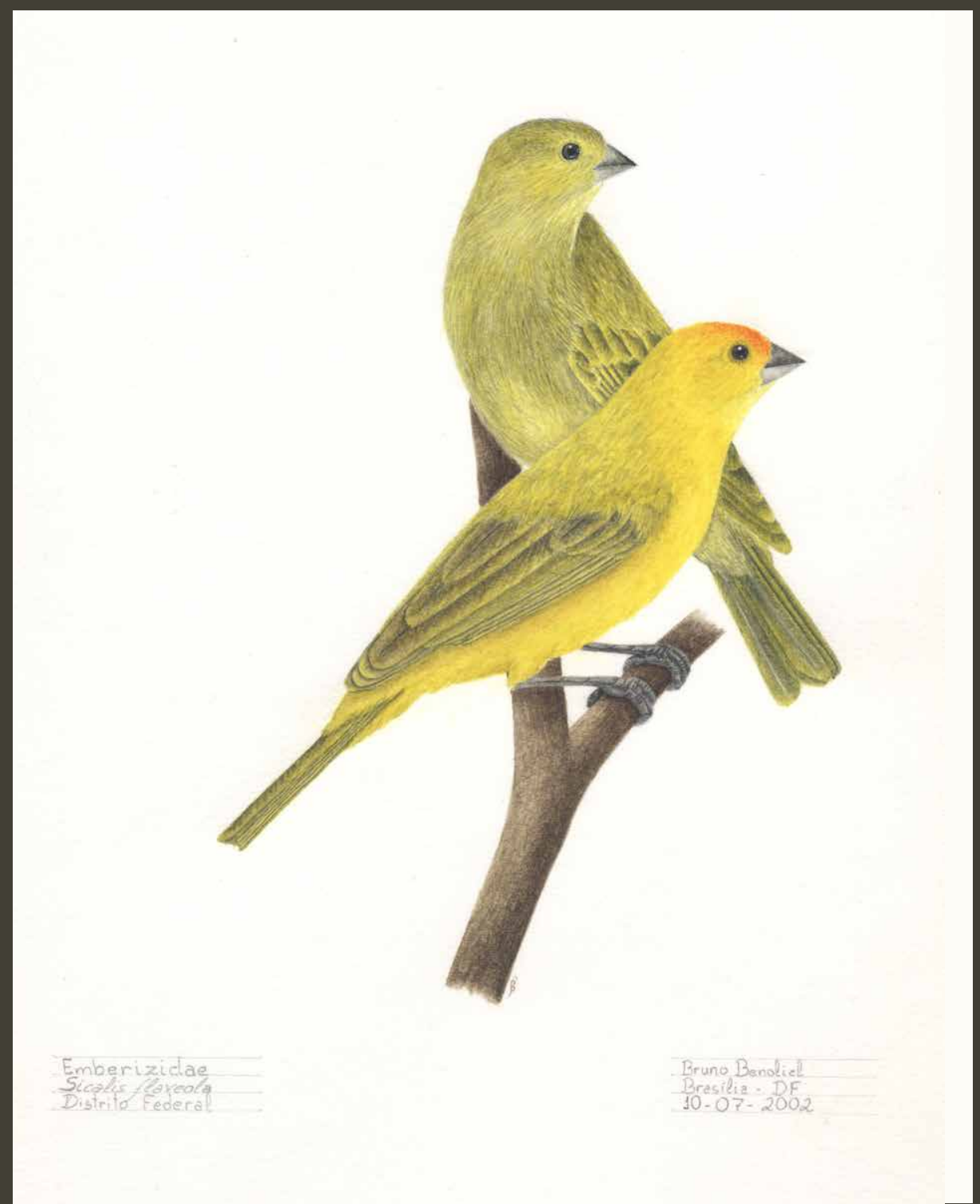

\section{Sicalis flaveola Linnaeus 1766}

O canário da terra verdadeiro tem um canto forte e melodioso, o que infelizmente o leva a ser aprisionado como ave de cativeiro, estando entre as 10 mais apreendidas pelo IBAMA. Tem cerca de $13,5 \mathrm{~cm}$ e 20 gramas. A fêmea e indivíduos jovens são mais oliváceos que os machos adultos. Alimentam-se de sementes no chão, graças a seu bico adaptado para esmagá-las, sendo por isso considerado predador e não dispersor de sementes. Ocasionalmente podem se alimentar de insetos. Vivem em grupos de algumas dezenas de indivíduos.

Bruno Benoliel - 2002
Sicalis flaveola Linnaeus 1766

This bird has the popular name of "canário da terra verdadeiro". Its call is strong and filled with melo$d y$, a fact that unfortunately makes him a prized cage species. It ranks among the ten species most commonly confiscated in the illegal wildlife trade in Brazil. It measures 13.5 centimeters and weighs 20 grams. Females and juveniles have a stronger tone of olive green than adult males. The eat seeds on the ground, using their specialized beaks that crush the seeds. Therefore, it is considered a seed predator, and not a seed disperser. Occasionally it eats insects. They live in groups of several dozen individuals.

Author: Bruno Benoliel - 2002 


\section{Theristicus caudatus Boddaert 1783}

A curicaca é uma ave com bico em forma de foice e com cauda curta. Podem atingir $69 \mathrm{~cm}$ de comprimento com uma envergadura de asa de cerca de $143 \mathrm{~cm}$. Ocorre em grande parte do Brasil. Possui uma dieta variada de insetos, larvas, pequenos lagartos e até ratos e pequenas cobras que encontram em campos de gramíneas ou em alagados. Vivem em bandos pequenos ou podem ser solitários. Gosta de planar a grandes alturas.

Marcos Santos-Silva - 2010

\section{Theristicus caudatus Boddaert 1783}

The "curicaca" has a beak shaped like a sickle and a short tail. It can have 69 centimeters in length and its wingspan can reach 143 centimeters. It is native to many regions of Brazil. It has a diversified diet of insects, larvae, small lizards and even rats and small snakes, which they forage in grassy fields or in shallow wetlands. They live in small groups, but some individuals lead solitary lives. It likes to glide at high altitudes.

Author: Marcos Santos-Silva - 2010

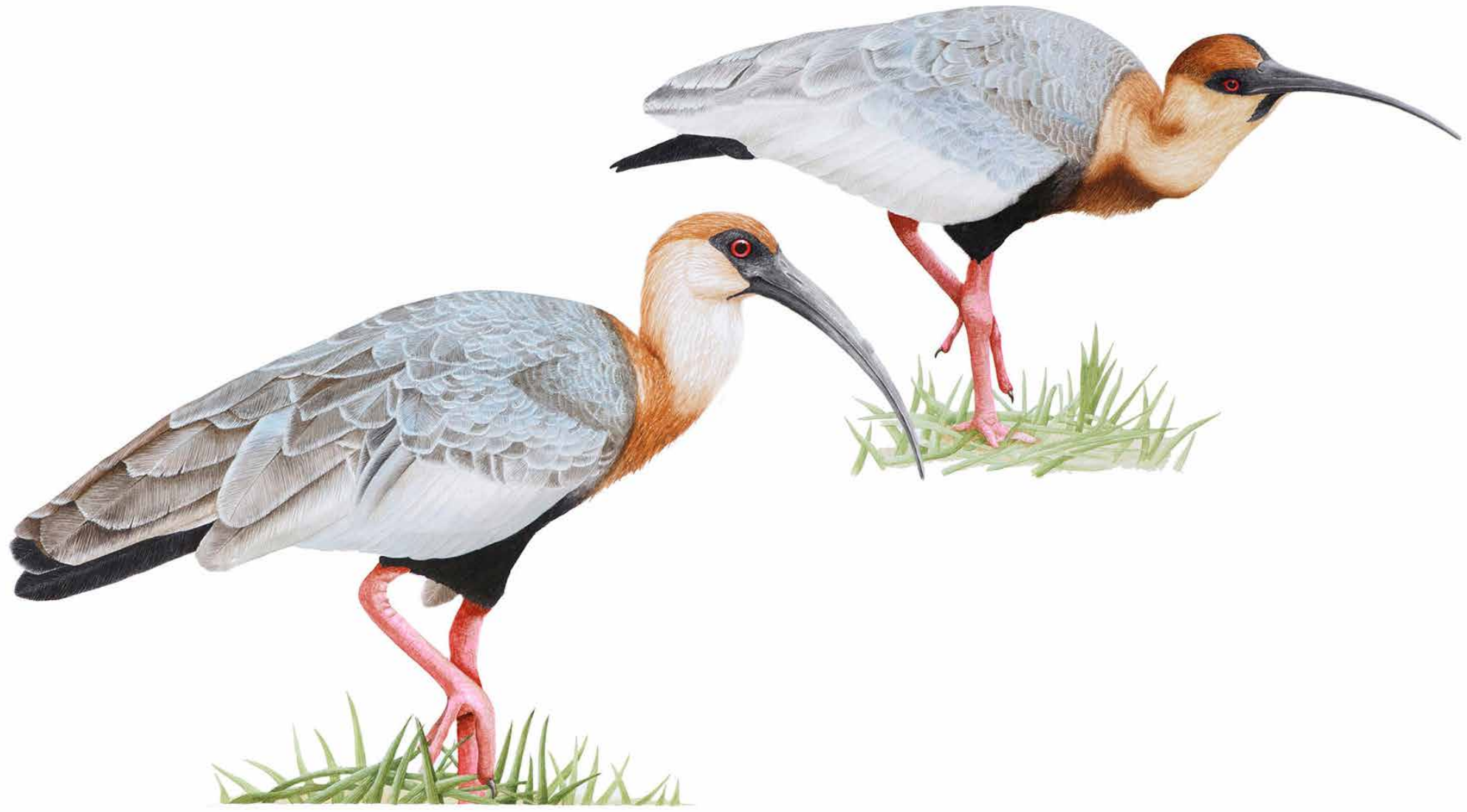

